Eur. J. Clin. Chem. Clin. Biochem.

Vol. 29, 1991, pp. $801-804$

(C) 1991 Walter de Gruyter \& Co. Berlin - New York

\title{
Chemical Analysis of Gallstones
}

\author{
By G. Steen and B. G. Blijenberg \\ Afdeling Klinisch Chemisch Laboratorium, Academisch Ziekenhuis Rotterdam-Dijkzigt, Rotterdam, Nederland
}

(Received March 25/October 9, 1991)

Summary: A new promising treatment for patients with symptomatic cholelithiasis is extracorporeal shock wave lithotripsy. In order to learn how to interpret the computed tomographic (CT) densities of gallstones measured in vivo, our radiologists asked the clinical chemistry laboratory to analyse cholesterol, bilirubin and calcium in gallstones. No reference methods for the analysis of gallstones have been described. A literature search for manageable quantitative methods for these analyses was not successful. Among the different Xray diffraction, infrared and chemical analyses described, we could find no well documented analyses that have been compared with reference methods or proposed reference methods for serum. This finding prompted us to develop chemical methods for cholesterol, bilirubin and total calcium in gallstones starting from (proposed) reference methods for serum and to investigate the accuracy, imprecision and linearity of these methods.

\section{Introduction}

Until a few years ago cholecystectomy was the only therapy for symptomatic gallstones, so the composition of the gallstones did not matter. Modern therapies include dissolution therapy and extracorporeal shock wave lithotripsy combined with dissolution therapy. Advantages of these therapies are: no operation required (under general anaesthesia) and lower costs. A disadvantage is the high frequency of recurrence. With respect to the composition of the stones, only stones or stone fragments with a cholesterol content above 80 per cent can be removed by dissolution therapy, possibly after extracorporeal shock wave lithotripsy, so that for pigment stones (less than $25 \%$ cholesterol) and mixed stones ( 25 to $80 \%$ cholesterol) cholecystectomy remains the only therapy (1).

Methods used for gallstone analysis include X-ray diffraction analysis, infrared analysis and chemical analysis. The latter two techniques are able to analyse most components in gallstones, while X-ray diffraction analysis is confined to crystalline components.
Like most investigations on the composition of gallstones, we restricted ourselves to cholesterol, bilirubin and calcium. The techniques used for the chemical analysis of cholesterol as well as bilirubin in general consist of an extraction step, followed by a chemical reaction and colorimetric analysis. The extraction step for both cholesterol and bilirubin can be carried out with e.g. acidified methanol-chloroform $(1+1$ by vol.) (2), while the extraction of cholesterol only can be carried out with isopropylalcohol (3). The measurement of cholesterol is carried out with non-enzymatic $(2,4-7)$ or enzymatic $(3,8)$ colorimetric methods or by GLC $(9,10)$. Bilirubin can be analysed colorimetrically according to Michaelson (2) or Weber \& Schalm (11). Sieg (3) determined the ratio, bilirubin/ conjugated bilirubin, by thin layer chromatography (TLC). Wosiewitz (10) determined calcium bilirubinate after extraction with Na-EDTA and Na-taurocholate solutions.

In most cases calcium is measured by atomic absorption spectrophotometry (AAS). Sieg (3) analysed calcium titrimetrically after dissociation of calcium from 
its components in the presence of $\mathrm{HCl}$. Nakayama (12) described a complicated system for the relatively complete quantitative microanalysis of gallstones using solvent partition, column chromatography and GLC procedures.

In nearly all the sources mentioned above, authors refer to literature on the chemical analyses of components in serum, but the performance of the complete analysis of gallstone components is not investigated sufficiently. One exception is Nakayama (12), who found a recovery of cholesterol of $91 \%$ and of bilirubin of $93 \%$. For the imprecision of cholesterol he found a CV of $0.7 \%$, for bilirubin $2.7 \%$ and for calcium 3.9\%. Another exception is Bell (6), who calculated a CV of $2.1 \%$ for the cholesterol analysis according to Abell et al. (13). Literature on X-ray diffraction analysis or infrared analysis of gallstones in general also does not document the performance of the methods used.

Comparing analytical results obtained with different techniques is of limited importance, e. g. infrared analysis measures $\mathrm{CaCO}_{3}$ and calcium bilirubinate separately, while chemical analysis results in total calcium.

Our aim is to develop modifications of (proposed) reference methods for the analysis of cholesterol and bilirubin in serum. The method for the analysis of calcium in gallstones is compared with an AASmethod. We investigated the imprecision, linearity and recovery of the complete analysis.

\section{Materials, Methods and Statistical Analysis}

Materials

Cholesterol was purchased from Sigma, St. Louis, MO, USA; $\mathrm{CaCO}_{3}$ pro analysis from Merck Darmstadt, Germany; bilirubin from Merck Darmstadt, Germany, and calcium bilirubinate was prepared according to Edwards (4).

\section{Methods}

\section{Sample pretreatment}

Gallstones were washed, dried superficially and weighed to the nearest $0.1 \mathrm{~g}$. After drying to constant weight (48 hours at $37^{\circ} \mathrm{C}$ ) the stones were weighed again. Gallstones or parts of them were ground in a mortar.

\section{Analysis of cholesterol}

Thirty $\mathrm{mg}$ of gallstone powder was transferred to $15 \mathrm{ml}$ glass tubes. Then $10 \mathrm{ml}$ of ethanol was added and the closed tubes were incubated at $50^{\circ} \mathrm{C}$ for 10 minutes to complete the dissolution of cholesterol. After standing at room temperature for another 10 minutes the tubes were centrifuged at $2000 \mathrm{~g}$ during 10 minutes. Then cholesterol was analysed manually according to $A$ bell et al. (13). This assay is linear from 0 to $10 \mathrm{mmol} / 1$.
Analysis of total bilirubin (bilirubin and calcium bilirubinate) and bilirubin

To a portion of $10 \mathrm{mg}$ of gallstone in a glass tube, $200 \mu \mathrm{l}$ of dimethylsulphoxide (DMSO) was added and the mixture incubated for half an our. Ten $\mu \mathrm{l}$ of $\mathrm{HCl}(12 \mathrm{~mol} / \mathrm{l})$ was added and incubation continued for another half hour to dissociate calcium bilirubinate. Then $5 \mathrm{mg}$ of EDTA was added to bind free calcium, and $100 \mu \mathrm{l}$ of $\mathrm{NaOH}(1.2 \mathrm{~mol} / \mathrm{l})$ to achieve a neutral $\mathrm{pH}$. The tube was made up to $5 \mathrm{ml}$ with bovine albumin solution $(40 \mathrm{~g} / \mathrm{l})$ in TRIS buffer $(0.1 \mathrm{~mol} / \mathrm{l}, \mathrm{pH} 7.4)$. The bilirubin concentration was measured on a SMAC instrument (Technicon, Tarrytown, New York, USA). This assay is linear from 0 to $500 \mu \mathrm{mol} / \mathrm{l}$. If $\mathrm{HCl}$ and EDTA are not added and $200 \mu \mathrm{I} \mathrm{Na}_{2} \mathrm{CO}_{3}(0.1 \mathrm{~mol} / \mathrm{l})$ is used instead of the $100 \mu \mathrm{l} \mathrm{NaOH}$, calcium bilirubinate does not dissociate, so only bilirubin reacts. The assay on the SMAC instrument correlated well with the assay according to Doumas et al. (14).

\section{Analysis of calcium}

\section{1. $o$-Cresolphthalein complexon method}

A portion of $25 \mathrm{mg}$ of gallstone powder was transferred to a $50 \mathrm{ml}$ volumetric flask. Five drops of concentrated $\mathrm{HCl}$ were added and after one minute $1 \mathrm{ml}$ of water was added. After one more minute the flask was made up to volume with water. After filtration the calcium content was analysed in duplicate using an $o$-cresolphthalein complexon method (15) on an EPOS 5060 instrument (Merck/Eppendorf, Hamburg, Germany). This assay is linear from 0 to $5 \mathrm{mmol} / \mathrm{l}$.

\section{Atomic absorption spectrometry}

AAS analysis of calcium in the filtrates described above was carried out on a Perkin Elmer $3030 \mathrm{~B}$ instrument with a Ca-Mg hollow cathode light source and an acetylene/air flame. The wavelength is $422.7 \mathrm{~nm}$. As a standard we used $\mathrm{CaCO}_{3} \cdot 4 \mathrm{H}_{2} \mathrm{O}, \mathrm{SRM} \# 915$, from the National Bureau of Standards. Samples and standards were diluted 41 times with $1 \mathrm{~g} / 1$ $\mathrm{LaCl}_{3} \cdot 7 \mathrm{H}_{2} \mathrm{O}$ before analysis (16). This assay is linear from 0 to $10 \mathrm{mmol} / \mathrm{l}$.

3. Calcium analysis (o-cresolphthalein complexon method) after ashing of gallstones

A $25 \mathrm{mg}$ portion of gallstone powder was dissolved in $250 \mu$ l $\mathrm{H}_{2} \mathrm{SO}_{4}(1 \mathrm{~mol} / \mathrm{l})$ in a porcelain cup. During one hour the $\mathrm{H}_{2} \mathrm{SO}_{4}$ was evaporated at $180^{\circ} \mathrm{C}$. The sample in the cup was ashed at $600^{\circ} \mathrm{C}$ until colorless, then cooled to room temperature in a desiccator. $\mathrm{HCl}(250 \mu \mathrm{l}, 370 \mathrm{~g} / \mathrm{kg})$ was added to the residue, followed 5 minutes later by $10 \mathrm{ml}$ of double-distilled water. The contents were transferred quantitatively to a $50 \mathrm{ml}$ volumetric flask and calcium was analysed as described above.

\section{Statistical analysis}

Within-run imprecision was calculated from duplicates, whereby the SD was assumed to be constant.

The linearity of cholesterol, bilirubin and calcium analyses was investigated by analysing a component in an increasing amount of gallstone powder, from 0 to twice the amount that is stated in the protocols above.

Accuracy was investigated by recovery experiments of cholesterol, bilirubin and calcium after adding increasing amounts of a stock solution to gallstones with different levels of the substance to be investigated.

Regression lines were calculated according to Passing \& Bablok (17).

.

Eur. J. Clin. Chem. Clin. Biochem. / Vol. 29, 1991 / No. 12 


\section{Results}

Table 1 demonstrates the results of within-run imprecision.

The linearity of the measurement of cholesterol in gallstones was investigated both in a pigment stone $(11.1 \%$ cholesterol) and in a cholesterol stone $(100 \%$ cholesterol) by increasing the amount of stone powder from 5 to $50 \mathrm{mg}$ per $10 \mathrm{ml}$ of ethanol $(\mathrm{n}=10)$.

Tab. 1. Within-run imprecision calculated from duplicates.

\begin{tabular}{llll}
\hline Component & $\begin{array}{l}\text { Range of } \\
\text { percentages }\end{array}$ & $\mathrm{n}$ & $\mathrm{SD}(\%)$ \\
\hline Cholesterol & $0.0-99.0$ & 10 & 1.0 \\
Bilirubin & $0.1-15.8$ & 25 & 0.4 \\
Calcium & $0.1-16.4$ & 25 & 0.3 \\
\hline
\end{tabular}

The check for linearity of the assay for total bilirubin in gallstones was carried out with two stones. No deviation from linearity was observed using increasing amounts $(\mathrm{n}=10)$ from 8 to $80 \mathrm{mg}$ powder from one stone ( 0.7 per cent bilirubin) and from 1.1 to $12 \mathrm{mg}$ powder from the other ( 30 per cent bilirubin) per $5 \mathrm{ml}$ of albumin solution.

The linearity of the calcium analysis in gallstones using the $o$-cresolphthalein complexon method also was investigated using two gallstones. To check linearity we used increasing amounts $(n=10)$ from 5.4 to $96 \mathrm{mg}$ powder from one stone ( 0.5 per cent calcium) and from $6.5 \mathrm{mg}$ to $91 \mathrm{mg}$ powder from the other (13.2 per cent calcium) per $50 \mathrm{ml}$ solution. For all three components no deviation from linearity was observed within the ranges investigated.

The results of the recovery experiments are shown in tables $2 \mathrm{a}, \mathrm{b}$ and $\mathrm{c}$.

To investigate whether our calcium assay does measure all calcium present in a stone we ashed 11 gallstones in duplicate and analysed total calcium. In cholesterol stones the calcium content assayed in this way correlated well with our $o$-cresolphthalein complexon $(\mathrm{CPC})$ assay. The regression line was $\mathrm{y}_{(\text {ashed) }}$ $=1.0541 \mathrm{x}_{(\mathrm{CPC})}+0.0428$ and the correlation coefficient was 0.9963 . Similar analyses in pigment stones are under investigation.

In 16 stones we analysed bilirubin and total bilirubin. The percentage bilirubin ranged from 0.3 to 5.4 and the total bilirubin percentage from 0.3 to 15.8 . On average, bilirubin made up 54 per cent of total bilirubin (range 8 to 100 per cent).
Tab. 2a. Recovery of cholesterol in gallstones.

\begin{tabular}{|c|c|c|c|c|c|}
\hline \multirow[t]{2}{*}{ ' } & \multirow{2}{*}{$\begin{array}{l}\text { Chol- } \\
\text { esterol } \\
(\%)\end{array}$} & \multirow{2}{*}{$\begin{array}{l}\text { Amount of } \\
\text { gallstone } \\
(\mathrm{mg} / 10 \mathrm{ml})\end{array}$} & \multirow{2}{*}{$\begin{array}{l}\text { Amount } \\
\text { of added } \\
\text { cholesterol } \\
(\mathrm{mg} / 10 \mathrm{ml})\end{array}$} & \multicolumn{2}{|c|}{$\begin{array}{l}\text { Recovery } \\
(\%)\end{array}$} \\
\hline & & & & mean & SD \\
\hline $\begin{array}{r}\text { Stone } 1 \\
2 \\
3\end{array}$ & $\begin{array}{r}0.5 \\
15.4 \\
92.9\end{array}$ & $\begin{array}{l}30 \\
30 \\
15\end{array}$ & $\begin{array}{l}0-30 \\
0-6 \\
0-16\end{array}$ & $\begin{array}{r}106.6 \\
81.7 \\
102.4\end{array}$ & $\begin{array}{l}1.8 \\
6.9 \\
3.2\end{array}$ \\
\hline
\end{tabular}

Tab. 2b. Recovery of bilirubin in gallstones.

\begin{tabular}{|c|c|c|c|c|c|}
\hline & \multirow{2}{*}{$\begin{array}{l}\text { Biliru- } \\
\text { bin } \\
(\%)\end{array}$} & \multirow{2}{*}{$\begin{array}{l}\text { Amount of } \\
\text { gallstone } \\
(\mathrm{mg} / 5 \mathrm{ml})\end{array}$} & \multirow{2}{*}{$\begin{array}{l}\text { Amount } \\
\text { of added } \\
\text { bilirubin } \\
(\mathrm{mg} / 5 \mathrm{ml})\end{array}$} & \multicolumn{2}{|c|}{$\begin{array}{l}\text { Recovery } \\
(\%)\end{array}$} \\
\hline & & & & mean & $\mathrm{SD}$ \\
\hline Stone 1 & $\begin{array}{l}0.3 \\
8.5\end{array}$ & $\begin{array}{l}10 \\
10\end{array}$ & $\begin{array}{l}0-0.5 \\
0-0.5\end{array}$ & $\begin{array}{l}97.0 \\
85.4\end{array}$ & $\begin{array}{l}5.0 \\
6.7\end{array}$ \\
\hline
\end{tabular}

Tab. 2c. Recovery of calcium in gallstones.

\begin{tabular}{|c|c|c|c|c|c|}
\hline & \multirow{2}{*}{$\begin{array}{l}\text { Cal- } \\
\text { cium } \\
(\%)\end{array}$} & \multirow{2}{*}{$\begin{array}{l}\text { Amount of } \\
\text { stone } \\
(\mathrm{mg} / 50 \mathrm{ml})\end{array}$} & \multirow{2}{*}{$\begin{array}{l}\text { Amount } \\
\text { of added } \\
\text { calcium } \\
(\mathrm{mg} / 50 \mathrm{ml})\end{array}$} & \multicolumn{2}{|c|}{$\begin{array}{l}\text { Recovery } \\
(\%)\end{array}$} \\
\hline & & & & mean & $\mathrm{SD}$ \\
\hline $\begin{array}{r}\text { Stone } 1 \\
2\end{array}$ & $\begin{array}{r}0.8 \\
14.5\end{array}$ & $\begin{array}{l}25 \\
25\end{array}$ & $\begin{array}{l}0-6 \\
0-6\end{array}$ & $\begin{array}{l}110.1 \\
107.4\end{array}$ & $\begin{array}{l}5.3 \\
8.8\end{array}$ \\
\hline
\end{tabular}

Within the range 0 to 4 per cent calcium, the results obtained with the $o$-cresolphthalein complexon method (CPC) were compared with AAS. The regression line was $\mathrm{y}_{(\mathrm{CPC})}=1.0211 \mathrm{x}_{(\mathrm{AAS})}+0.0222$ and the correlation coefficient was $0.9999(n=25)$.

\section{Discussion}

Infrared analysis of gallstones has been used for a long time, e. g. Toyoda (18) analysed calcium bilirubinate and total pigment as early as 1966. Although some investigators have analysed a large number of different components in gallstones (e.g. Trotman et al. (7) describe 9 components, while Nakayama (12) even describes the analysis of 16 different components), cholesterol, bilirubin and calcium are the most important ones.

In gallstone analysis obviously infrared analysis has advantages if compared with chemical analysis: it is quick, it analyses all components at one time, and it requires only a small amount of sample. Disadvantages are that instrumentation for infrared analysis is not available in most laboratories, and that the performance of infrared analysis strongly depends on disc preparation. 
The protocols for the analysis of cholesterol and calcium described above were used in a study of the prediction of gallstone composition by CT analysis in vitro as well as in vivo, conducted by Brakel et al. (1). The results of the chemical analysis performed by the clinical chemistry department, using gallstones obtained by cholecystectomy from fifty patients with cholelithiasis, served as a gold standard. Of the stones, 37 were cholesterol stones and 13 were mixed or pigment stones. An inverse relationship was found to exist between $\mathrm{CT}$ attenuation numbers and cholesterol content, and there was a good positive correlation

Tab. 3. Ranges in composition of 50 (69) random stones obtained by cholecystectomy.

\begin{tabular}{llll}
\hline & $\begin{array}{l}\text { Cholesterol } \\
\text { stones }\end{array}$ & $\begin{array}{l}\text { Mixed } \\
\text { stones }\end{array}$ & $\begin{array}{l}\text { Pigment } \\
\text { stones }\end{array}$ \\
\cline { 2 - 4 } & $\mathrm{n}=37$ & $\mathrm{n}=5$ & $\mathrm{n}=8$ \\
\hline Cholesterol & $80-100$ & $55-78$ & $0.0-18$ \\
Calcium & $0-7.4$ & $0.4-14$ & $0.0-28.5$ \\
Total bilirubìn & $0-2.3$ & $0.3-6.4$ & $1.1-15.8$ \\
\hline
\end{tabular}

\section{References}

1. Brakel, K., Laméris, J. S., Nijs, H. G. T., Terpstra, O. T., Steen, G. \& Blijenberg, B. G. (1990) Predicting gallstone composition with $\mathrm{CT}$ : an in vivo and in vitro study. Radiology 174, 337-341.

2. Baron, R. L., Rohrmann, C. A., Lee, S. P., Shuman, W. P. \& Teefey, S. A. (1988) CT evaluation of gallstones in vitro: correlation with chemical analysis. Am. J. Radiol. 151, $1123-1128$

3. Sieg, A., Metz, W., Stiehl, A., Raedsch, R., Wysocki, S., Kohlmeier, M. \& Kommerell, B. (1986) Zusammensetzung von Gallenblasen- und Gallengangssteinen. Dtsch. Med. Wochenschr. 111, 1760-1762.

4. Edwards, J. D., Wilbert, D., Adams, B. S. \& Halpert, B. (1958) Infrared spectrums of human gallstones. Am. J. Clin. Pathol. 29, 236-238.

5. Malet, P. F., Dabezies, M. A., Huang, G., Long, W. B., Gadacz, T. R. \& Soloway, R. D. (1988) Quantitative infrared spectroscopy of common bile duct gallstones. Gastroenterology 94, 1217-1221.

6. Bell, G. D., Dowling, R. H., Whitney, B. \& Sutor, D. J. (1975) The value of radiology in predicting gallstone type when selecting patients for medical treatment. Gut 16, $359-364$.

7. Trotman, B. W., Ostrow, J. D. \& Soloway, R. D. (1974) Pigments vs cholesterol cholelithiasis: comparison of stone and bile composition. Digestive Diseases 19, 585-590.

8. Wei, J. S., Huang, H. M., Shuy, W. C..\& Wu, C. S. (1989) Simple enzymatic determination of total cholesterol in gallstones. Clin. Chem. 35, 2247-2249.

9. Whiting, M. J., Jarvinen, V. \& Mck Watts, J. (1980) Chemical composition of gallstones resistent to dissolution therapy with chenodeoxycholic acid. Gut $21,1077-1081$.

10. Wosiewitz, U., Schenk, J., Sabinski, F. \& Schmack, B. (1983) Investigations on common bile duct stones. Digestion 26 , $43-52$. between CT attenuation numbers and calcium content. The authors conclude that with their instrumentation a CT number smaller than $140 \mathrm{HU}$ (Hounsfield Units) indicates a pure cholesterol stone (cholesterol content above $80 \%$ ). The importance of the in vivo results with respect to treatment is obvious. The results of our analyses of fifty' gallstones randomly obtained by cholecystectomy are shown in table 3.

Vergunst et al. (19) carried out an in-vitro comparison of different gallstone dissolution solvents, also using the protocols described here.

Based on the results of reproducibility, linearity and recovery, we feel that the results of gallstone analysis using our protocols for chemical analysis are good. The amount of gallstone powder necessary for the analyses of cholesterol, calcium and bilirubin is $65 \mathrm{mg}$.

\section{Acknowledgements}

We wish to thank Miss $H$. A. Roetering, Miss $P$. Lie, Miss $B$. v.d. Berg, Mr. L Zwang and Mr. T. L. Liem for their technical support.
11. Weber, A. Ph. \& Schalm, L. (1962) Quantitative separation and determination of bilirubin and conjugated bilirubin in human serum. Clin. Chim. Acta 7, 805-810.

12. Nakayama, F. (1968) Quantitative microanalysis of gallstones. J. Lab. Clin. Med. 72, 602-611.

13. Abell, L. L., Levy, B. B., Brodie, B. B. \& Kendall, F. E. (1952) A simplified method for the estimation of total cholesterol in serum and determination of its specificity. $J$. Biol. Chem. 195, 357-366.

14. Doumas, B. T., Kwok-Cheung, P. P., Perry, B. W., Jendrzejczak, B., McComb, R. B., Schaffer, R. \& Hause, L. L. (1985) Candidate reference method for determination of total bilirubin in serum: development and validation. Clin. Chem. 31, 1779-1789.

15. Baginski, E. S., Marie, S. S., Clark, W. L. \& Zak, B. (1973) Direct microdetermination of serum calcium. Clin. Chim. Acta 46, 49-54.

16. Bowers, G. N. \& Pybus, J. (1972) Total calcium in serum by atomic absorption spectrophotometry. In: Standard methods of clinical chemistry, Volume 7, pp. 143-150. Academic Press, New York.

17. Passing, H. \& Bablok, W. (1983) A general regression procedure for method transformation, application of linear regression procedures for method comparison studies in clinical chemistry, part 1 . J. Clin. Chem. Clin. Biochem. $21,709-720$

18. Toyoda, M. (1966) Quantitative determination of calcium bilirubinate in gallstones by infrared spectroscopy. Tohuku J. Exp. Med. 90, 303-316.

19. Vergunst, H., Terpstra, O. T., Nijs, H. G. T. \& Steen, G. (1991) In vitro comparison of different gallstone dissolution solvents. Gut $32,211-214$.

G. Steen
Klinisch Chemisch en
Bacteriologisch Laboratorium
Stichting Ziekenhuizen Rijnland
Postbus 4220
NL-2350 CC Leiderdorp

